\title{
Improved Technique for Estimating Milk Production from Range Cows
}

\section{JAMES S. BLUNTZER AND PHILLIP L. SIMS}

Highlight: Calf weaners, commonly called "blabs," were found to be useful devices to aid in collection of milk consumption data in range animal nutrition research. Inserting $a$ blab in the calf's nostril prevents the calf from nursing when cow and calf are turned out to graze. Calves are then weighed, allowed to nurse, and then reweighed. The difference in the two weighings was considered to be the amount of milk consumed by the calf or produced by the cow for that time interval. This procedure is an improvement over that suggested by other investigators, as both the cow and calf remain together and graze more normally, as opposed to the calves' being penned for 12 hours.

In the past, milk production in beef cattle has been evaluated indirectly by measuring weight gain of the calf during the preweaning period. Hall (1971), Rutledge et al. (1971), and Knapp and Black (1941), studying factors that influence 205-day weight of beef calves, verify that milk production of the beef cow has greater influence on weaning weight of her calf than any other single factor.

At a recent symposium on the range beef cow, increased milk production and improved fertility of range cows were stressed as two primary areas for increasing efficiency of beef production in the future (Great Plains Agricultural Council, 1973). Therefore, quantifying milk production by different

Authors are graduate research assistant and associate professor, Range Science Department, Colorado State University, Fort Collins 80521 . At present $\mathrm{J}$. Bluntzer is working as a range technician II for Chillicothe-Vernon Experiment Research and Extension Center, Vernon, Texas.

Manuscript received May 2, 1975. breeds and various crossbreeds seems important in determining the most efficient type of cow-calf unit for utilizing and converting range forage into high protein human foods (Bluntzer, 1974).

\section{Procedures}

Twelve ( $1 / 2$ Hereford $\times 1 / 2$ Angus) crosbred cows and their calves grazing sandhill range in northeastern Colorado were used in this milk study for seven 3-consecutive day trials. Bluntzer (1974) employed the use of calf weaners commonly called "blabs" in collecting milk records, using similar weigh-suckle-weigh procedures as Drewry et al. (1959). The blabs (Fig. 1) are 10.2 by $20.3 \mathrm{~cm}$ metal rectangles with three sharp points and a nose clamp. These devices prevent the calf from nursing during the 12-hour separation interval, but allow the calf to graze somewhat normally. Thus, the need to pen calf and disturb cow's normal grazing habits was avoided.

Actual procedures used are as follows: In mid-afternoon cow and calves were separated 2 to 3 hours. This preliminary separation was to insure that the cow's udders would be depleted of milk just prior to the time blabs were inserted at 6 pm. At 6 am the following day, after the first 12-hour interval, blabs were taken out, calves were weighed, allowed to nurse, and reweighed. Again blabs were placed in calves' nostrils and cow and calf turned out to graze. After another twelve hours the weigh-suckle-weigh procedure was repeated at $6 \mathrm{pm}$. The sum of the two differences in before-and-after-weights for this 24-hour period has been commonly accepted as an accurate determination of daily milk yield (Totusek and Arnett, 1965).

JOURNAL OF RANGE MANAGEMENT 29(2), March 1976 
Table 1. Average milk consumption (kg/day) for seven 3-day calf nursing trials on sandhill rangeland in eastern Colorado during the preweaning period, using blabs to improve the weigh-suckle-weigh procedure.

\begin{tabular}{|c|c|c|c|c|c|c|c|c|c|c|}
\hline $\begin{array}{c}\text { Calf } \\
\text { no. }\end{array}$ & $\begin{array}{c}\text { April } \\
13\end{array}$ & $\begin{array}{c}\text { May } \\
4\end{array}$ & $\begin{array}{c}\text { June } \\
1\end{array}$ & $\begin{array}{c}\text { June } \\
29\end{array}$ & $\begin{array}{c}\text { July } \\
27\end{array}$ & $\begin{array}{c}\text { August } \\
24\end{array}$ & $\begin{array}{c}\text { September } \\
14\end{array}$ & Mean & \pm & S.E. ${ }^{1}$ \\
\hline 268 & - & 6.2 & 8.0 & 6.1 & 6.0 & 5.8 & 6.0 & 6.4 & & .34 \\
\hline 271 & - & 5.2 & 7.2 & 7.1 & 6.5 & 5.2 & 4.7 & 6.0 & & .44 \\
\hline 272 & - & 4.0 & 6.9 & 6.7 & 6.7 & 5.9 & 5.2 & 5.9 & & .46 \\
\hline 274 & - & 7.3 & 7.9 & 7.6 & 7.0 & 5.8 & 4.6 & 6.7 & & .50 \\
\hline 275 & 5.9 & 6.2 & 7.6 & 8.1 & 7.6 & 6.6 & 5.6 & 6.8 & & .42 \\
\hline 277 & 6.3 & 6.8 & 5.8 & 6.6 & 6.4 & 6.2 & 4.6 & 6.1 & & .28 \\
\hline 279 & 6.3 & 6.4 & 8.4 & 8.0 & 8.7 & 4.6 & 5.0 & 6.8 & & .62 \\
\hline 280 & 5.7 & 5.7 & 6.7 & 6.0 & 4.2 & 3.1 & 2.0 & 4.8 & & .65 \\
\hline 281 & 8.0 & 8.4 & 9.0 & 9.5 & 9.5 & 7.9 & 5.9 & 8.3 & & .30 \\
\hline 282 & 5.7 & 6.2 & 5.5 & 6.8 & 6.3 & 6.6 & 3.8 & 5.9 & & .38 \\
\hline 283 & - & 6.5 & 7.2 & 8.4 & 6.0 & 5.5 & 4.3 & 6.3 & & .56 \\
\hline 284 & - & 5.8 & 5.7 & 7.4 & 5.4 & 5.3 & 4.5 & 5.7 & & .39 \\
\hline Mean & 6.3 & 6.3 & 7.2 & 7.4 & 6.7 & 5.7 & 4.7 & 6.3 & & .27 \\
\hline$(\text { S.E. })^{1}$ & $(.53)$ & $(.43)$ & $(.65)$ & $(.62)$ & $(.67)$ & $(.58)$ & $(.43)$ & & & \\
\hline
\end{tabular}

${ }^{1}$ St andard error based on daily milk consumption.

\section{Precautions}

The calf nursing procedure has some room for error in use. Use of improper size blabs may result in their loss and, subsequently, missing data. Different types of blabs can be purchased in at least two different sizes. The authors found the smaller blab of the type illustrated to have the best retention during the separation periods. Care should be taken not to bend the metal flange on the blab that locks the clamp in the nostrils, as this may allow a blab to be lost.

Urination or defecation between the time the calf is first weighed and then reweighed is a source of error that should be considered, as this will reduce the weight difference that should show up as milk consumed by the calf.

Finally, total milk production by the cow may be biased if the calf does not consume all of the milk produced by the cow.

\section{Results}

Table 1 shows data obtained at the Eastern Colorado Range Research Center near Akron, Colo., in 1973 on the group of

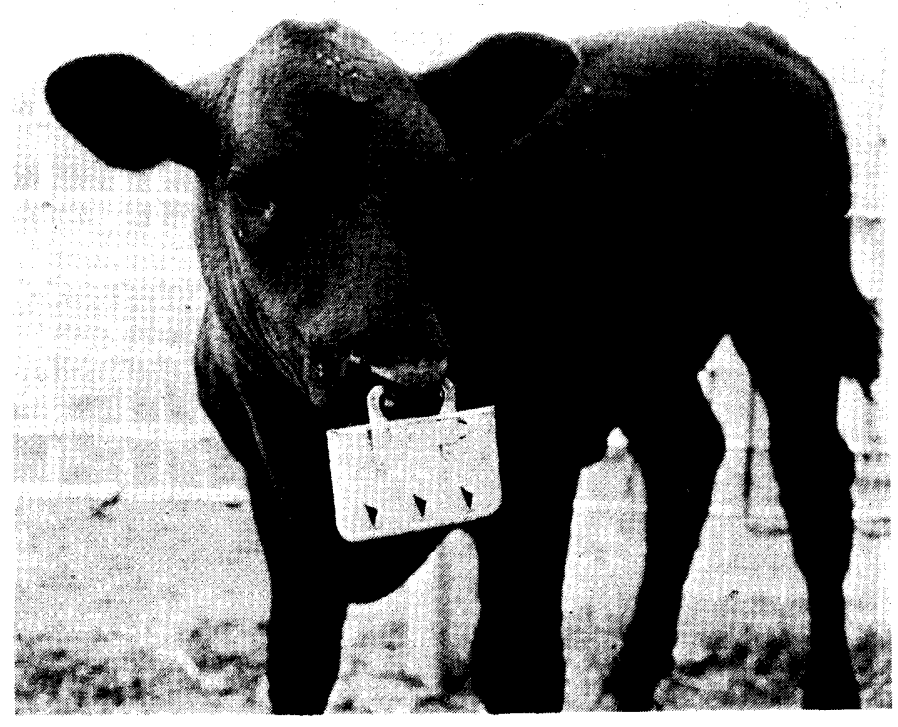

Fig. 1. Calf blab used in milk study that prevents calf from nursing, yet allows normal grazing activity. crossbred cattle studied. Average milk production by this group of range cows was $6.3 \pm .27 \mathrm{~kg} / \mathrm{day}$. The range in milk yield varies from a low of $4.7 \mathrm{~kg} / \mathrm{day}$ in September to a high of $7.4 \mathrm{~kg} /$ day in late June. For comparison, Herefords on similar vegetation had a lower yield of $4.0 \pm .28 \mathrm{~kg} / \mathrm{day}$, while similar Herefords on a limited ration in total confinement had even a lower yield of $2.4 \pm .36 \mathrm{~kg} /$ day. The authors found range cows varying in daily milk yield from 1.8 to $9.1 \mathrm{~kg}$ (4 to 20 pounds). Hand milking after the calf finished nursing yielded an additional $0.6 \pm .04 \mathrm{~kg} /$ day of milk during the first month of lactation.

\section{Conclusions}

In summary, the calf nursing technique using blabs is a useful tool in range animal nutrition studies. The authors agree with Neville (1962), who states that calves appear to remove all the milk from the udder at each nursing; however, he further states that this is probably not the case shortly after calving. This technique is useful under range conditions to quantify milk yield of different breeds and crossbreeds. It may also be used to show seasonal variation in milk production and to determine the energy flow to the calf as milk and its efficiency of conversion into pounds of salable beef.

\section{Literature Cited}

Bluntzer, J. S. 1974. Partial energy budget of the range calf. MS Thesis. Colorado State Univ., Fort Collins. 58 p.

Drewry, D. C., C. J. Brown, and R. S. Honea. 1959. Relationships among factors associated with mothering ability in beef cattle. J. Anim. Sci. 18:938-946.

Great Plains Agricultural Council. 1973. Great Plains Beef Symposium, Range and Livestock Management Committee. May 29-31, 1973. Univ. of Nebraska.

Hall, T. H. 1971. Seasonal variation of milk production in beef cows. Colorado S tate Univ. Exp. Sta. P. R. 714.

Knapp, Bradford, Jr., and W. H. Black. 1941. Factors influencing rate of gain of beef calves during the suckling period. J. Agr. Res. 63:249-254.

Melton, A. A., J. K. Riggs, L. A. Nelson, and T. C. Cartwright. 1967. Milk production, composition, and calf gains of Angus, Charolais, and Hereford cows. J. Anim. Sci. 26:804-809.

Neville, W. E., Jr. 1962. Influence of dam's milk production and other factors on 120- and 240-day weight of Hereford cows. J. Anim. Sci. $21: 315-320$.

Rutledge, J. J., 0. W. Robison, W. T. Ahlshwede, and J. E. Legates. 1971. Milk yield and its influence on 205-day weight of beef calves. J. Anim. Sci. 33:563-567.

Totusek, Robert, and Dudley Arnett. 1965. Estimates of milk production in beef cows. J. Anim. Sci. 24:906/(Abstr.). 